\title{
Domestic Legal System of the Yellow Sea States for the Prevention of Vessel-Source Pollution under the UNCLOS: A Comparative Legal Study
}

\author{
Junghwan Choi*
}

As a semi-enclosed sea, the Yellow Sea is shared by costal states such as China, South Korea and North Korea which have common interests in this maritime area. This situation requires special attention and mutual efforts for the protection and preservation of the coastal waters and marine ecosystem. The Yellow Sea contains many shipping routes, and it is potentially exposed to the risks of vessel-source pollution. This research has examined how the Yellow Sea states have implemented the International Maritime Organisation conventions relating to vessel-source pollution at the domestic level through a comparative legal study. The objective of this research is to understand current national laws of the Yellow Sea states dealing with the prevention of vessel-source pollution and to emphasize the necessity of regional efforts and cooperation to implement global regulatory instruments in order to protect and preserve the marine environment from the threats of international shipping activities.

\section{Keywords}

Vessel-Source Pollution, Semi-enclosed Sea, Marine Environmental Protection Law, Ocean Protection Law, Marine Environment Management Act

* Lecturer at Law School of Dalian Maritime University, China. LL.M. (Korea Maritime \& Ocean U.), LL.M. (Swansea U.), Ph.D. (Exeter). ORCID: https://orcid.org/0000-0001-8527-3371. The author may be contacted at: junghwanchoi@ dlmu.edu.cn / Address: Law School, Dalian Maritime University, No.1 Liaoning Road, Dalian, Liaoning 116026, P.R. China. 


\section{Introduction}

Oceans cover approximately 70 percent of the earth's surface, ${ }^{1}$ which contain about 98 percent of water on earth. ${ }^{2}$ The chemical and physical role of seawater has a significant effect on every ecosystem around the globe. Furthermore, the ocean is a rich ground for renewable resources. For thousands of years, both the fishing and shipping industries have depended on the oceans. As human activities are intricately connected to the ocean, its significance to our economic activities will be surely rising in the future. In recent, however, the ocean serves as a final destination for various pollutants and the discharge of various kinds of pollutants into the sea, coupled with indiscriminate development, has been seriously devastating to the ocean environment. As a result, the ocean is gradually losing its ability to assimilate contaminants.

The marine environment and resources of the Yellow Sea are closely connected to the socio-economic situations of costal States. As a semi-enclosed sea, the Yellow Sea has a number of geographical disadvantages. The Yellow Sea is relatively shallow, with an average depth of 44 metres and a maximum depth of 100 metres. ${ }^{3}$ It does not exceed the width of 400 nautical miles between China and the Korean peninsula. ${ }^{4}$ As such, there is no part of the high sea. The Yellow Sea includes an area of overlapping exclusive economic zones (EEZs) between China and South Korea. China and North Korea have not reached the arrangement of maritime delimitation over EEZ in the North Yellow Sea. ${ }^{5}$ Pollution incidents originating from the coastal waters of one state may result in serious marine pollution to another state bordering the Yellow Sea. In addition to land-based pollution, a primary cause of the deteriorating marine environment of the Yellow Sea, various pollutants from ships have also contributed to exacerbating marine pollution.

For many years, the Yellow Sea played a crucial role as an indispensable international shipping route. Accordingly, various pollutants from ships have contributed to accelerating marine pollution. Although the International Maritime Organization (IMO) provides a global regulatory framework for the international

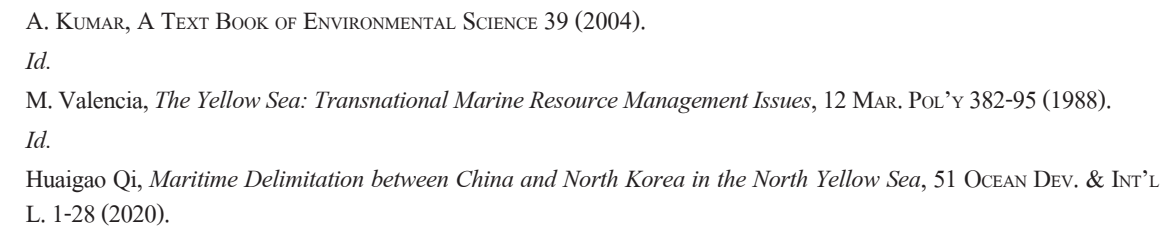


shipping industry to protect the marine environment, the implementation of the IMO conventions wholly relies on the ratification by member states. The varied status of the ratification of the IMO conventions reveals the differing views of member states, depending on their influence over the global shipping industry and particular economic situations.

The primary purpose of this research is to analyse the domestic legal approaches of the Yellow Sea states against vessel-source pollution. For this purpose, this paper will scrutinize how these countries transpose the IMO conventions into their domestic laws. In this regard, the author considers whether or not the constitutions of the Yellow Sea states refer expressly and specifically to provisions relating to the doctrine of transformation or incorporation and to the general principle or obligation to protect the marine environment. Then, this paper will scrutinize the domestic laws related to the prevention of vessel-source pollution through a comparative legal study. This paper is composed of four parts including Introduction and Conclusion. Part two will discuss the concurrent jurisdiction over the prevention of vessel-source pollution in the Yellow Sea. Part three will examine the domestic laws of the Yellow Sea states over the prevention of vessel-source pollution.

\section{Concurrent Jurisdiction over the Prevention of Vessel-Source Pollution in the Yellow Sea}

\section{A. The Yellow Sea in Danger from the Risks of International Shipping Activities}

Today, more than 80 percent of global trade involves ocean transport. ${ }^{6}$ Shipping is the most efficient and cost-effective international transportation mode for most goods. ${ }^{7}$ Moreover, shipping industry is closely related to the development of the global and national economy alike. As such, shipping industry is also essential to economic prosperity and human development in the region around the Yellow Sea.

The Yellow Sea also plays a crucial role as a major international shipping route for the coastal states. For instance, China is exerting a great influence on shipping

6 UNCTAD, Review of Maritime Transport 2020 (Nov. 12, 2020), https://unctad.org/webflyer/review-maritimetransport-2020.

7 IMO, Introduction to IMO 2021, http://www.imo.org/en/About/Pages/Default.aspx. 
industry as a biggest exporter and importer in the world. ${ }^{8}$ South Korea has approximately 99 percent of dependence upon foreign trade by shipping. ${ }^{9}$ Significant part of North Korea-China trade depends on the Yellow Sea shipping route, as well. These countries have ports and oil or LNG terminals along the coastal regions of the Yellow Sea. This implies that the Yellow Sea has a strong possibility of being contaminated by various types of vessel-source pollutants unless the coastal states continue to make regulatory efforts to combat vessel-source pollution.

Figure 1: The Yellow Sea

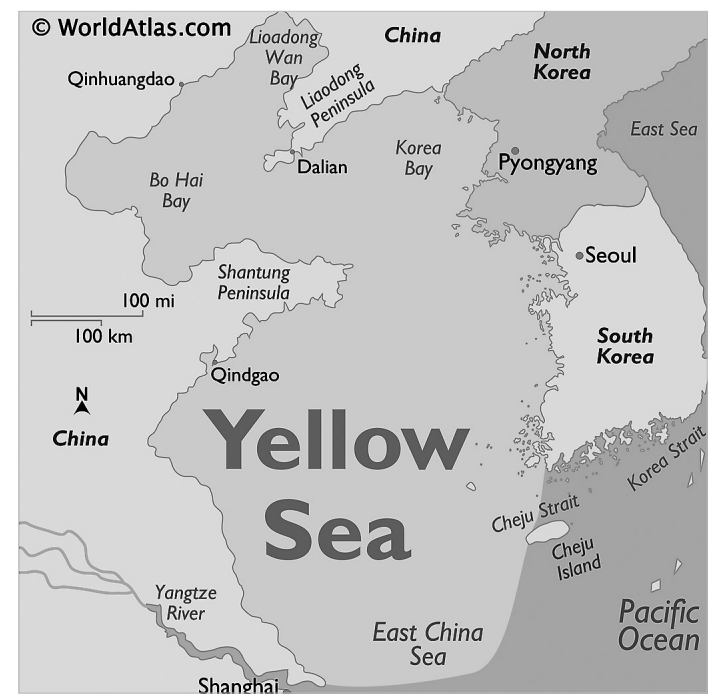

Source: Worldatlas, https://www.worldatlas.com/seas/yellow-sea.html.

As one of semi-enclosed seas around the global, it is difficult for the Yellow Sea's marine environment to recover after contamination due to the region's geographical feature. Since China, South Korea, and North Korea have a common interest in the Yellow Sea, marine pollution cases that occur in maritime zone of one state may inevitably affect another state. The efforts of one state alone are thus not enough to maintain or restore the marine environment of the Yellow Sea. In particular, as vessel-source pollution often results in trans-boundary contamination and accidental discharges from ships can occur anywhere and anytime, regional cooperation

8 UNCTAD, supra note 6, at 6.

9 Yeong Seok Ha, Keun Jon Chung, \& Jung Soo Seo, An Analysis of Korea-ASEAN Trade and its Implications for the Shipping Industry in Korea, 32(2) Asian J. SHIPPING Logistics 63-71 (2016). 
between the Yellow Sea states is necessary to prevent vessel-source pollution beforehand or to minimise already occurred pollution. If oil or HNS pollution occurs in the disputed areas, however, the polluted state may have difficulty in enforcing jurisdiction, filing claims for pollution damage, and assigning responsibility. In recent, the disputes regarding maritime boundary delimitation in the Yellow Sea are major obstacles to regional cooperation.

\section{B. The Effect of Maritime Boundary Disputes on the Prevention of Vessel-Source Pollution in the Yellow Sea}

Because of ongoing disputes over maritime boundary delimitation in the Yellow Sea, ${ }^{10}$ concurrent Chinese and South Korean jurisdictions exist. In particular, these disputes are hampering regional cooperation in the overlapping EEZ area regarding the international rules of marine pollution liability.

Figure 2: EEZ Dispute of the Yellow Sea between South Korea and China

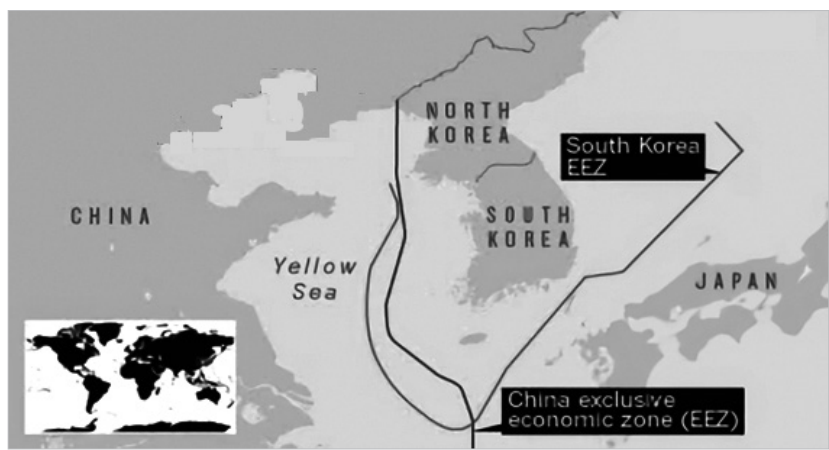

Source: Nature, https://www.nature.com/articles/528318a

The United Nations Convention on the Law of the Sea (UNCLOS) ${ }^{11}$ allows coastal states to exercise prescriptive jurisdiction so as to prevent marine pollution from ships in their maritime zones in accordance with "generally accepted international rules and standards." ${ }^{, 12}$ Under Articles 220(3), (5), and (6) of the UNCLOS, coastal states

10 Suk-Kyoon Kim, Maritime Boundary Negotiations between China and Korea: The Factors at Stake, 32 INT'L J. MAR. \& CoAstal L. 29-94 (2017).

11 United Nations Convention on the Law of the Sea (adopted Dec. 10 1982; entered into force Nov. 16, 1994), 1833 U. N.T.S. 397, https://www.un.org/depts/los/convention_agreements/texts/unclos/unclos_e.pdf.

12 K Hakapää, Marine pollution in International Law: Material Obligations and Jurisdiction with Special Reference to the Third United Nations Conference on the Law of the Sea 120 (1981). See also A. Boyle, Marine Pollution 
can exercise enforcement jurisdiction with respect to the prevention of vessel-source pollution against foreign vessels in EEZs and their territorial waters if clear evidence exists that foreign vessels have violated international rules and standards for the prevention, reduction, and control of pollution from vessels or laws and regulations of the state. ${ }^{13}$ As the key to the IMO instruments for the prevention of vessel-source pollution, Articles 4 and 5 of the International Convention for the Prevention of Pollution from Ships 1973, as modified by the Protocol of 1978 (MARPOL73/78) ${ }^{14}$ also prescribe the enforcement jurisdiction regime concerning the ships that have violated discharge standards in conformity with the UNCLOS. These articles may also lead to concurrent jurisdictions over vessel-source pollution in overlapping EEZ areas unless countries have regional agreements governing the exercise of jurisdiction in the disputed areas.

Furthermore, the domestic laws of South Korea and China do not address this issue. ${ }^{15}$ It may be difficult for their governments to promptly respond to oil pollution or HNS pollution incidents occurred in the disputed area since the exercise of enforcement jurisdiction by China and South Korea has been restricted. Finally, a legal vacuum would exist in their jurisdiction over vessel-source pollution in this area.

\section{Ratifications of the IMO Conventions by the Yellow Sea States}

With regard to the international legal regimes over vessel-source pollution, the IMO conventions have played a more practical role in preventing vessel-source pollution than Part XII of the UNCLOS, because the IMO conventions are specific examples of the "international rules and standards" of Part XII of UNCLOS in exercising state jurisdiction over vessel-source pollution. ${ }^{16}$

In the shipping industry, the IMO conventions regarding the prevention of

under the Law of the Sea Convention, 79 Aм. J. INT'L L. 347-72 (1985).

13 UNCLOS art. 220.

14 International Convention for the Prevention of Pollution from Ships 1973 (Convention), 1978 (1978 Protocol), 1997 (Protocol-Annex VI), entered into force Oct. 2, 1983 (Annexes I \& II), 1340 U.N.T.S. 61.

15 J. van Dyke, Maritime Boundary Disputes, Settlement Processes and the Law of the Sea, in DisPuTES OVER ISLANDS AND Maritime Boundaries in East Asia 56 (Seoung-Yong Hong \& J. van Dyke eds., 2009); J. van Dyke, The Republic of Korea's Maritime Boundaries, 18(4) Int'L J. Mar. \& CoAstal L. 509-40 (2003); J. Prescott, Maritime Jurisdiction in East Asian Seas 45 (East-West Enviornment and Policy Institute Occasional Paper No.4, 1987), https://scholarspace. manoa.hawaii.edu/bitstream/10125/21627/MaritimeJurisdictionin EastAsianSeas1987\%5Bpdfa\%5D.PDF; D. JoHNSTON \& M. Valencia, Pacific Ocean Boundary Problems: Status and Solutions 116 (1991).

16 G. Timagenis, International Control of Marine Pollution 605-7 (1980). See also Boyle, supra note 12, at 355-7; Ho Sam Bang, Port State Jurisdiction and Article 218 of the UN Convention on the Law of Sea, 40(2) J. MAR. L. \& CoM. 291-313 (2009); R. Beckman \& Zhen Sun, The Relationship between UNLCOS and IMO Instruments, 2 AsIA-PAC. J. OCEAN L. \& POL'Y 201-46 (2017). 
vessel-source pollution are the most effective regulatory instruments at the global level. However, the fundamental limitation in applying or implementing the IMO conventions in the maritime zone between states with opposite or adjacent coasts exists if the key IMO conventions have not been ratified. As the ratification of the IMO conventions may directly affect the global shipping industry, member states tend to ratify them firstly considering their national interests or industrial benefits. The Yellow Sea states are no exception.

Table 1: Status of Ratifications by China, South Korea, and North Korea ${ }^{17}$

\begin{tabular}{|l|c|c|c|}
\hline \multicolumn{1}{|c|}{ IMO Conventions } & China & South Korea & North Korea \\
\hline MARPOL 1973/1978 (ANNEX I\& II) & $\mathrm{R}$ & $\mathrm{R}$ & $\mathrm{R}$ \\
\hline MARPOL ANNEX III & $\mathrm{R}$ & $\mathrm{R}$ & $\mathrm{R}$ \\
\hline MARPOL ANNEX IV & $\mathrm{R}$ & $\mathrm{R}$ & $\mathrm{R}$ \\
\hline MARPOL ANNEX V & $\mathrm{R}$ & $\mathrm{R}$ & $\mathrm{R}$ \\
\hline MARPOL PROT 1997(ANNEX VI) & $\mathrm{R}$ & $\mathrm{R}$ & $\mathrm{R}$ \\
\hline INTERVENTION 1969 & $\mathrm{R}$ & $\mathrm{X}$ & $\mathrm{X}$ \\
\hline INTERVENTION PROT 73 & $\mathrm{R}$ & $\mathrm{X}$ & $\mathrm{X}$ \\
\hline CLC1992 & $\mathrm{R}$ & $\mathrm{R}$ & $\mathrm{X}$ \\
\hline FUND1992 & $\mathrm{X}$ & $\mathrm{R}$ & $\mathrm{X}$ \\
\hline FUND PROT 2003 & $\mathrm{X}$ & $\mathrm{R}$ & $\mathrm{X}$ \\
\hline HNS PROT 2010 & $\mathrm{X}$ & $\mathrm{X}$ & $\mathrm{X}$ \\
\hline BUNKER 2001 & $\mathrm{R}$ & $\mathrm{R}$ & $\mathrm{R}$ \\
\hline OPRC 1990 & $\mathrm{R}$ & $\mathrm{R}$ & $\mathrm{X}$ \\
\hline OPRC-HNS2000 & $\mathrm{R}$ & $\mathrm{R}$ & $\mathrm{X}$ \\
\hline BWM 2004 & $\mathrm{X}$ & $\mathrm{R}$ & $\mathrm{X}$ \\
\hline
\end{tabular}

R: Ratification, X: Non-Ratification

As shown in Table 1, first, the Yellow Sea states will be able to apply the same discharge regulations in accordance with MARPOL 73/78 to ships flying the flag of another state within the Yellow Sea because the Yellow Sea states have ratified all annexes of MARPOL 73/78. Meanwhile, the International Convention Relating to Intervention on the High Seas in Cases of Oil Pollution Casualties 1969

17 IMO, Status of Conventions-Ratifications by State, http://www.imo.org/en/About/Conventions/StatusOfConventions/ Documents/StatusOfTreaties.pdf. 
(INTERVENTION 1969) and its Protocol $1973^{18}$ have been only ratified by China. Therefore, South and North Korea are yet unable to take such measures on the high seas as may be necessary to prevent, mitigate, or eliminate grave and imminent danger to their coastline or related interests from pollution or threat of pollution of the sea by oil following a maritime casualty. Responding to pollution emergencies, China and South Korea have established national contingency plans to take proper measures in the event of oil or HNS pollution incidents from ships under the International Convention on Oil Pollution Preparedness, Response, and Cooperation 1990 (OPRC 1990) ${ }^{19}$ and Protocol on Preparedness, Response and Co-operation to pollution Incidents by Hazardous and Noxious Substances 2000 (OPRC-HNC). ${ }^{20}$

Secondly, the Yellow Sea states address different positions concerning civil liability regimes for oil pollution damage. In this regard, the International Convention on Civil Liability for Bunker Oil Pollution Damage, 2001 (BUNKER 2001) ${ }^{21}$ has been ratified by all the Yellow Sea states. However, North Korea has not yet ratified a major regime of civil liability for pollution damage such as International Convention on Civil Liability for Oil Pollution Damage 1992 (CLC 1992)22 or International Convention on the Establishment of an International Fund for Compensation for Oil Pollution Damage 1992 (FUND 1992). ${ }^{23}$ Moreover, China has established a compensation regime under CLC 1992, but not yet ratified FUND 1992. It implies that, while South Korea has the ability to compensate for pollution damage caused by oil incidents under the three-tier phase by extending the compensation regime from CLC 1992 to FUND 2003, China can cover pollution damage under CLC 1992. There is no applicable international compensation regime for oil pollution damage by North Korea. The lack of uniformity regarding the international regimes of civil liability for oil pollution among the Yellow Sea states means that those who have suffered damage caused by oil spills in the disputed sea area may be unable to access

18 International Convention Relating to Intervention on the High Seas in Cases of Oil Pollution Casualties, 1969 (adopted Nov. 29, 1969; entered into force May 6, 1975), 970 U.N.T.S. 211.

19 International Convention on Oil Pollution Preparedness, Response, and Cooperation 1990 (adopted Nov. 30, 1990; entered into force May 13, 1995), 1891 U.N.T.S. 51.

20 Protocol on Preparedness, Response and Co-operation to pollution Incidents by Hazardous and Noxious Substances, 2000 (adopted Mar.15, 2000; entered into force June 14, 2007). 2007 A.T.S. 41.

21 International Convention on Civil Liability for Bunker Oil Pollution Damage, 2001 (adopted Mar. 23, 2001; entered into force on Nov. 21, 2008).

22 International Convention on Civil Liability for Oil Pollution Damage (CLC) (adopted 29 November 1969, enter into force 19 June 1975; being replaced by 1992 Protocol: Nov. 27, 1992; entered into force May 30, 1996), 1956 U.N.T.S. 255.

23 International Convention on the Establishment of an International Fund for Compensation for Oil Pollution Damage (FUND) (adopted Dec. 18, 1971; entered into force Oct. 16 1978, superseded by 1992 Protocol: adopted Nov. 27 1992; entered into force May 30, 1996), 1953 U.N.T.S. 330. 
a comprehensive and international liability and compensation regime. For instance, it is uncertain whether those who suffered pollution damage in the maritime zone of North Korea can receive compensation for pollution damage appropriately. Also, if oil pollution incidents occur in the overlapping areas of the EEZ between China and South Korea, it may be unclear whether the claimant in such incidents can receive compensation under the FUND 1992. This situation may arise because China has only adopted and implemented CLC 1992.

Thirdly, the International Convention for the Control and Management of Ships' Ballast Water and Sediments (BWM) ${ }^{24}$ has only been ratified by South Korea. According to the principle of "no more favourable treatment" under the BWM, South Korea may apply discharge standards for ships' ballast waters against foreign vessels flying the flag of a non-contracting party to the BWM. Despite the need for the comprehensive and unified application of discharge standards in the Yellow Sea, however, the different ratifications of the BWM among the Yellow Sea states may be a bar to enforcing such discharge standards in the disputed area in the Yellow Sea. It may also lead to the weakening of enforcement jurisdiction.

\section{Domestic Laws of the Yellow Sea States for the Prevention of Vessel-source Pollution: A Comparison}

\section{A. China}

\section{General Principles}

In principle, China adopts international treaties and conventions in domestic law through the doctrine of incorporation or transformation. ${ }^{25}$ The Constitution of the People's Republic of China [中华人民共和国宪法] (hereinafter PRC Constitution) grants the right to conduct and conclude treaties or agreements with foreign states to the State Council. ${ }^{26}$ Meanwhile, the right to decide on the ratification and abrogation of treaties and important agreements concluded with other states is given to the

24 International Convention for the Control and Management of Ships' Ballast Water and Sediments (adopted Feb. 13, 2004; entered into force Sept. 8, 2017), 1760 U.N.T.S. 142.

25 Keyuan Zou, International Law in the Chinese Domestic Context, 44 Valparaiso U. L. Rev. 935-56 (2009). See also Xue Hanqin \& Jin Qian, International treaties in the Chinese domestic legal system, 8 CHINESE J. INT'L L. 299-322 (2009).

26 P.R.C. Const. art 89(9). 
Standing Committee of the National People's Congress. ${ }^{27}$ This constitutional principle is expressly and specifically governed by the Law of the People's Republic of China on the Procedure of the Conclusion of Treaties. (hereinafter Treaty Procedure Law)

Although the PRC Constitution does not provide any explicit provisions for the priority of international treaties or conventions concluded by the State Council over national laws, it may be possible to infer such a priority between treaties and national laws based on the relevant provisions of individual laws. ${ }^{28}$ Article 5, paragraph 3 of the PRC Constitution states: "No law or administrative or local rules and regulations shall contravene the Constitution." 29 Article 78 of the Law on Legislation also stipulates: "The Constitution has the highest legal authority, and no national law, administrative regulation, local decree, autonomous decree and special decree, or administrative or local rule may contravene the Constitution. ${ }^{30}$ It means that the PRC Constitution takes precedence over all other national laws, treaties, and conventions with a greater importance. ${ }^{31}$ While the decisions of the Standing Committee of the National People's Congress regarding treaties or agreements with foreign states may have the same force as national laws (as per Article 3 of the Treaty Procedure Law), international treaties or agreements concluded and adopted in the name of the People's Republic of China require the examination and approval of the State Council, which bear the same validity and effect as administrative regulations do.

Under the PRC Constitution, it is a fundamental obligation of the state to protect the environment. After China ratified the MARPOL 73/78 and all its technical annexes, ${ }^{32}$ China enacted the Marine Environmental Protection Law (MEPL) in 1982, which was amended in 1999. As per the administrative regulation, the State Council promulgated the Regulation on the Prevention and Control of Marine Pollution from Vessels 1983 (hereinafter 1983 Regulation). ${ }^{33}$ In addition, Article 26, paragraph 1 of the PRC Constitution requires the state to protect and improve the living and ecological environment, as well as to prevent and remedy pollution and other public hazards.

27 Id. art. 67(14).

28 Individual law of China contains: Treaty Procedure Law [中华人民共和国缔结条约程序法]; Law on Legislation of the People's Republic of China (Law on Legislation) [中华人民共和国立法法]; General Principles of the Civil Law of the People's Republic of China (Civil Law) [中华人民共和国民法总则]. See Xue \& Jin, supra note 25, at 299-322 (2009).

29 P.R.C. Const. art. 5.

30 Law on Legislation art 78.

31 Xue \& Jin, supra note 25 , at 302.

32 "As early as 1983, China ratified MARPOL and its Annexes I and II. China also ratified MARPOL Annex III (1994), Annex IV and VI (2006), Annex V (1988), and SOLAS (1994)." See Nengye Liu, China's Law and Practice as a Coastal State for the Prevention of Vessel-Source Pollution, 29(1) OCEAN Y.B. 343-55 (2015).

33 Ling Zhu, Bingying Dong \& Kevin X. Li, Compensation for Oil Pollution Damage from Ships in China: A Way toward International Standards 44 OCEAN Dev. \& INT'L L. 73-95 (2013). 


\section{The Marine Environmental Protection Law}

To implement the MARPOL 73/78 and Part XII of the UNCLOS at the domestic level, the Standing Committee of the National People's Congress promulgated the MEPL in 1982 and fully amended it in 1999. As the basic law of China regarding the protection of the marine environment, the 1999 MEPL deals with the regulations for preventing and controlling the pollution damage to the marine environment by land-based pollutants, coastal and marine construction projects, and the dumping of wastes and vessels. Chapter 8 of the 1999 MEPL refers specifically to the prevention of marine pollution from ships. ${ }^{34}$

Firstly, as per the general provisions, the geographical scope of the 1999 MEPL is the internal waters, territorial seas, contiguous zones, EEZs and continental shelves of China, as well as all other sea areas under the jurisdiction of China. ${ }^{35}$ Concerning the meaning of "other sea areas under the jurisdiction of China," there is no clear explanation in the 1999 MEPL, although the Territorial Sea and Contiguous Zone Law was adopted in 1992 and the Exclusive Economic Zone and Continental Shelf Law was adopted in $1998 .^{36}$ Accordingly, the question may arise as to whether and in which way China can exercise its jurisdiction in disputed sea areas or overlapping areas of EEZs to prevent and control vessel-source pollution. It is argued that China may be unable to unilaterally conduct some activities in these sea areas absent any agreements or cooperation with the neighbouring state. ${ }^{37}$

As to the prevention of vessel-source pollution in the 1999 MEPL, the discharge of any pollutants, waste, ballast water, vessel garbage, or other harmful substances in violation of the provisions of this law into the sea is strictly prohibited. ${ }^{38}$ Article 63 of the 1999 MEPL requires vessels to carry certificates and documents for preventing the pollution to the marine environment and to make factual records of pollutant discharges and other operations in accordance with relevant regulations. ${ }^{39}$ The term "relevant regulations" is defined in the 2010 Regulation on the Prevention and Control of Vessel-Induced Pollution to the Marine Environment (hereinafter 2010 Regulation), which provides more detailed provisions for marine pollution from

\footnotetext{
34 Nengye Liu, Prevention of Vessel-Source Pollution in the South China Sea: What Role Can China Play?, 15 AsIA PaC. J. EnVtL. L. 147-66 (2013).

35 PRC Marine Environment Protection Law [中华人民共和国海洋环境保护法], art 2.

36 Nengye Liu \& Frank Maes, Prevention of Vessel-Source Marine Pollution: A Note on the Challenges and Prospects for Chinese Practice Under International Law, 42 OcEan Dev. \& InT'L L. 356-67 (2011). 
ships as a sub-decree of the 1999 MEPL. ${ }^{40}$

Article 65 of the 1999 MEPL requires vessels to be equipped with corresponding pollution prevention facilities and equipment. ${ }^{41}$ All ships must comply with the stipulations of the marine traffic laws and regulations and endeavour to prevent marine environment pollution from incidents resulting from collision, grounding, stranding, fire, or explosions and the like. ${ }^{42}$ Pursuant to Article 66 of the 1999 MEPL, the government must not only establish civil liability compensation systems resulting from oil pollution damage, but also set up oil pollution insurance and compensation fund systems in accordance with the principle of the owners of the vessels and the cargoes jointly undertaking liabilities for vessel-induced oil pollution compensation. ${ }^{43}$ Notwithstanding this provision, if neighbouring states that have shared interest in disputed sea areas have established different compensation regimes or legal systems, it may not be easy to solve the compensation issues for oil pollution damage in the event of maritime casualties in disputed sea areas.

Article 71 of the 1999 MEPL grants the right to take appropriate measures regarding ships involved in maritime incidents causing or possibly resulting in major pollution damages to the marine environment to the China Maritime Safety Administration (MSA). ${ }^{44}$ Article 71 provides a legal basis to exercise port state control by the China MSA. In addition, the China MSA may implement necessary measures to respond to pollution which has occurred or may possibly occur on the high seas. ${ }^{45}$ Article 71 of the 1999 MEPL conforms to Article 221 of the UNCLOS and the 1969 INTERVENTION. ${ }^{46}$

In particular, the MSA may impose administrative sanctions on or assign criminal responsibility to those in violation of the 1999 MEPL. ${ }^{47}$ The MEPL does not provide criminal penalties and specific circumstances as per which criminal responsibility may be imposed in the event of vessel-source pollution. Instead, one may be able to derive such an answer from the Criminal Law of the People's Republic of China (hereinafter PRC Criminal Law). Article 338 of the PRC Criminal Law imposes

\footnotetext{
40 The 2010 Regulation was adopted by the Standing Committee of the National People's Congress on September 2, 2009 and entered into force on March 1, 2010. The 2010 Regulation replaced the1983 Regulation on the Prevention and Control of Vessel-Source Pollution [防治船舶污染海洋环境管理条例].

41 PRC Marine Environment Protection Law, art 65.

42 Id.

$43 \quad I d$. art. 66.

44 Id. art. 71 .

45 Id.

46 Liu \& Maes, supra note 36, at 358.

47 PRC Marine Environment Protection Law, arts. 73, 74 \& 88. See Liu \& Maes, supra note 36, at 156.
} 
a specific term of imprisonment (e.g. not more than three years) on those who "discharge, dump, or treat radioactive waste, waste containing pathogen of infectious toxic substances, or other hazardous waste on the land or in the water bodies or the atmosphere." ${ }^{, 48}$ Hence, Article 338 applies to those who cause a major environmental pollution accident which leads to the serious consequences of heavy losses of public or private property or human casualties. ${ }^{49}$

\section{The 2010 Regulation on the Prevention and Control of Marine Pollution from} Ships

As a sub-decree of the MEPL of China, the 2010 Regulation was enacted to prevent and remove pollution to the marine environment from ships and relevant ship operation activities pursuant to the 1999 MEPL. The 2010 Regulation offers more detailed provisions than the 1999 MEPL, which focusses on vessel-source pollution. Like the 1999 MEPL, the 2010 Regulation applies to all ships and their operational activities within the sea areas under China's jurisdiction. ${ }^{50}$ In particular, Article 10 of the 2010 Regulation requires a vessel to comply with the international conventions ratified or acceded to by China in relation to ships' construction, equipment, and facilities, as well as to obtain and carry on board the necessary certificates and documents relating to the prevention and control of marine pollution. ${ }^{51}$

The 2010 Regulation is the Chinese domestic law that incorporated MARPOL $73 / 78$ and all technical annexes. Article 11 of the 2010 Regulation also requires the owners, operators, and managers of ships flying the Chinese flag to establish safety management for preventing marine pollution from ships. ${ }^{52}$ Such a safety management system should correspond with the International Safety Management (ISM) Code, which is a mandatory regulation under Chapter IX of the International Convention for the Safety of Life at Sea (SOLAS). Furthermore, ships flying the Chinese flag or any foreign-flagged vessel navigating within the maritime jurisdiction of China must comply with international treaties or conventions ratified or acceded to by China for controlling the discharge of the vessel's garbage, sewage, oil mixture, and other pollutants. $^{53}$

According to Article 11 of the 2010 Regulation, the IMO conventions ratified

48 PRC Criminal Law [中华人民共和国刑法], art 338.

49 Id.

50 Regulations of the People's Republic of China on the Prevention and Control of Marine Pollution from Ships [防治 船舶污染海洋环境管理条例], art 1.

51 Id. art. 10.

52 Id. art. 11.

53 Id. art. 15. 
or acceded to by China may be implemented to the same effect as that of domestic laws over all ships. The discharge of any kinds of pollutants into protected marine reservation areas, coastal scenic spots, important fishery waters, and other areas that need special protection is strictly prohibited..$^{54}$ In accordance with the MARPOL 73/78 Annex I, the 2010 Regulation contains the regulations relevant to port reception facilities. Companies engaged in the reception of ships' pollutants must obtain a permit from the MSA and comply with relevant laws and regulations concerning pollutant reception and disposal. ${ }^{55}$

\section{Regulation for the Discharge of Ships' Ballast Waters}

China's sea areas are suffering from a serious threat to marine ecology and biodiversity caused by ships' ballast waters. ${ }^{56}$ Although China has not yet ratified the BWM, Article 62 (1) of the 1999 MEPL regulates that: "All vessels shall not discharge any pollutants, wastes, ballast water, garbage, and other noxious substances into sea areas under China's jurisdiction.” While Article 15 of the 2010 Regulation prohibits the discharge of ballast water within the maritime jurisdiction of China in accordance with the laws, regulations, international conventions, and relevant standards ratified or acceded to by China, the 1999 MEPL and the 2010 Regulation do not refer to specifically or expressly detailed requirements in regulating the discharge of ships' ballast waters. $^{57}$

Aside from the 1999 MEPL and the 2010 Regulation, policymakers may need to pay attention to whether or not the Frontier Health and Quarantine Law of China (FHQL) deals with the regulations regarding the discharge of ships' ballast waters. Article 18 of the FHQL stipulates that frontier health and quarantine officers may supervise and inspect the disposal of garbage, waste matter, sewage, excrement, and ballast water, and any ballast water filled in cholera-prevalent areas is not allowed to be discharged or unloaded without disinfection under Article 78(6) of the Implementation Rules of the FHQL. ${ }^{58}$ However, the FHQL remains silent on the

54 Id. art. 15.

55 Id. art. 19.

56 Wu Huixian et al., The biological content of ballast water in China: A review, 2(6) Aquaculture \& Fisheries 241-6 (2017).

57 Liu Nengye, China: Prevention of Invasive Species from Ballast Water, 28 InT'L J. MArine \& Coastal L. 17187 (2013). See also Zheng Wan, Jihong Chen \& Dan Sperling, Institutional Barriers to the Development of a Comprehensive Ballast-Water Management Scheme in China: Perspective from a Multi-Stream Policy Model, 91(1) Marine Pol'y 142-9 (2018); Hee Cheol Yang, Entry into Force of Ship Ballast Water Management Convention and its Implementation from Perspective of Northeast Asia, 1 J. Int'L Mar. Safety, Envtl. AfF. \& Shipping 19-21(2017).

58 PRC Frontier Health and Quarantine Law [中华人民共和国国境卫生检疫法], art 78(6). 
operational or technical requirements for the discharge of ships' ballast waters. The Chinese legislation only regulates the prohibition of the discharge of ships' ballast waters within sea areas falling within China's jurisdiction and does not impose any operational or technical requirements. ${ }^{59}$ The lack of specific regulations with respect to ships' ballast waters may weaken law enforcement in the EEZ and disputed sea areas. ${ }^{60}$

\section{Domestic Emission Control Area}

The threat to the environment and the chronic harm to public health caused by air pollution from ships is one of global concerns. Annex VI of MARPOL 73/78 has been adopted to reduce, control, and prevent air pollution from ships at the global level. As with other annexes to the MARPOL 73/78, Annex VI enables the state to establish the Emission Control Areas (ECAs), which are sea zones for stricter controls to minimise ship-generated emissions. ${ }^{61}$ Currently, the Baltic Sea area (SOx), the North Sea area (SOx), the North American area (SOx and NOx), and the United States Caribbean Sea area (SOx and NOx) have been designated as ECAs. ${ }^{62}$

Over the past decades, the Chinese shipping industry has undergone rapid growth. In 2019, approximately 33 percent of the world containers were handled in Chinese ports. ${ }^{63}$ According to the UNCTAD, "seven of the top 10 container ports are in China, and nearly half of the volumes handled by the top 40 rankings in 2016 were attributed to container ports in China." ${ }^{\circ 4}$ Given this fact, China may be more highly exposed to the threat of air pollution from ships and various marine pollutants than other countries. In December 2015, the PRC Ministry of Transport (MOT) announced that the Pearl River Delta, the Yangtze River Delta, and the Bohai Sea Water Area would be designated as domestic emission control areas (DECA) from January 1, 2016. ${ }^{65}$ The legal basis of DECA arises from Article 64 of the Atmospheric Pollution Prevention and Control Law of the People's Republic of China (hereinafter PRC

59 Wan, Chen \& Sperling, supra note 57, at 143.

60 Yang, supra note 57, at 21.

61 MARPOL73/78, annex VI, regs.13 \&14.

62 Id. See also IMO, Special Areas under MARPOL (2021), https://www.imo.org/en/OurWork/Environment/Pages/ Special-Areas-Marpol.aspx.

63 UNCTADSTAT, Container port throughput (2020), https://unctadstat.unctad.org/wds/TableViewer/tableView.aspx? ReportId=13321.

64 Huan Liu et al., Shipping Emission Forecasts and Cost-Benefit Analysis of China Ports and Key Regions' Control, 236 Envtl. Pollution 19-59 (2018).

65 Mo Zhu et al., Incentive Policy for Reduction of Emission from Ships: A Case Study of China, 86 MARINE PoL'y 253-8 (2017). See also China Classification Society European Centre, China Emission Control Area Implementation (2017), https://www.egcsa.com/regulatory/china-deca. 
Air Pollution Prevention Law). Article 64 provides: "The competent transportation department of the State Council may designate atmospheric pollutant emission control areas in coastal regions, where vessels entering the area are required to meet related vessel emission standards." ${ }^{" 66}$ Accordingly, the MOT established the "China ECAs Implementation Scheme." ${ }^{\prime 67}$

China has designated three sea waters (Pearl River Delta, the Yangtze River Delta, and the Bohai Sea) as DECAs through PRC Air Pollution Prevention Law (not as per Annex VI of MARPOL 73/78). The China ECAs implementation scheme applies to all commercial vessels, which must use fuel oil with a sulphur content of no more than 0.50 percent $\mathrm{m} / \mathrm{m}$ within designated waters. ${ }^{68}$ Moreover, the operational requirements for the sulphur content of ships' fuel oil in Chinese DECAs are strengthened through the following four phases.

As of the first phase, since January 1, 2017, all vessels at berth in 11 designated core ports within DECAs must use fuel oil with a sulphur content of no more than 0.5 percent $\mathrm{m} / \mathrm{m}$, or they must have equivalent emission reduction measures, such as the installation of an exhausted gas scrubber. The core ports within DECAs are as follows: Tianjin, Qinhuangdao, Tangshan, and Huanghua in the Bohai Sea; Shanghai, Ningbo-Zhoushan, Suzhou, and Nantong in the Yangtze River Delta; and Shenzhen, Guangzhou, and Zhuhai in Pearl River Delta. ${ }^{69}$ In the second phase, all vessels at berth in all DECA ports must use fuel oil with a sulphur content not exceeding 0.5 percent $\mathrm{m} / \mathrm{m}$ as of January 1, 2018. During the third phase, all vessels within Chinese DECAs must fulfil the requirement for a 0.5 percent $\mathrm{m} / \mathrm{m}$ sulphur limit of ships' fuel oil as of January 1, 2019. At the fourth phase, after completing the assessment of the impact of DECAs, the MOT will take into account additional measures for achieving either a lower sulphur content limit of not more than 0.5 percent $\mathrm{m} / \mathrm{m}$, or the enlargement of DECAs in Chinese waters. ${ }^{70}$

The decision of the Chinese government to set up DECAs in Chinese waters may play a significant role as an institutional instrument in reducing and controlling air pollution from ships in the future. Even though the legal basis of the Chinese ECA is not governed by any global convention such as Annex VI of the MARPOL 73/78, the China ECAs Implementation Scheme will sufficiently contribute to the prevention,

66 PRC Atmospheric Pollution Prevention and Control Law [中华人民共和国大气污染防治法], art 64(1).

67 Gard, China expands its sulphur emission control areas (Dec. 17, 2018), https://www.gard.no/web/updates/ content/26771455/china-expands-its-sulphur-emission-control-areas.

68 China Classification Society European Centre, supra note 65, at 2.

69 Id.

70 Zhu et al., supra note 65 , at 254. 
reduction, and control of ship-generated air pollution by limiting the sulphur content of ships' fuel oil.

\section{B. South Korea}

\section{General Principles}

For the implementation of the IMO conventions or international treaties in national laws, South Korea adopts the doctrine of transformation. Concerning the validity of treaties on the domestic level, Article 6 of the Constitution of the Republic of Korea (hereinafter ROK Constitution) expressly stipulates: "Treaties duly concluded and promulgated under the constitution and the generally recognised rules of international law shall have the same effect as the domestic laws of the Republic of Korea." ${ }^{, 71}$ Moreover, the status of aliens shall be guaranteed as prescribed by international law and treaties. ${ }^{72}$ Such a principle can also be found in the domestic legislation of South Korea. All major IMO conventions ratified by South Korea have also been promulgated in national laws by means of transformation, as displayed in Table 2 below.

Table 2: Domestic Laws of South Korea and Major IMO Conventions ${ }^{73}$

\begin{tabular}{|l|l|}
\hline \multicolumn{1}{|c|}{ ROK Municipal Laws } & \multicolumn{1}{c|}{ IMO Conventions } \\
\hline Maritime Safety Act & SOLAS, 1966 LL and its Protocol, 1972 CSC \\
\hline Ship Act & 1969 Tonnage \\
\hline Ship Personnel Act and Seafarers' Act & $\begin{array}{l}\text { 1978 STCW, 1995 Amendments, 2010 } \\
\text { Amendments }\end{array}$ \\
\hline $\begin{array}{l}\text { Act on the Arrival, Departure of Ships, } \\
\text { Maritime Safety Act }\end{array}$ & 1972 COLREG \\
\hline Marine Environment Management Act & $\begin{array}{l}\text { MARPOL 73/78, all technical annexes, } \\
\text { OPRC 1990 and OPRC/HNS 2000 }\end{array}$ \\
\hline Ballast Water Management Act & BWM 2004 \\
\hline $\begin{array}{l}\text { Compensation for Oil Pollution } \\
\text { Damage Guarantee Act }\end{array}$ & $\begin{array}{l}\text { 1992 CLC, 1992 FUND and its 2003 Protocol, } \\
\text { and 2004 Bunker }\end{array}$ \\
\hline
\end{tabular}

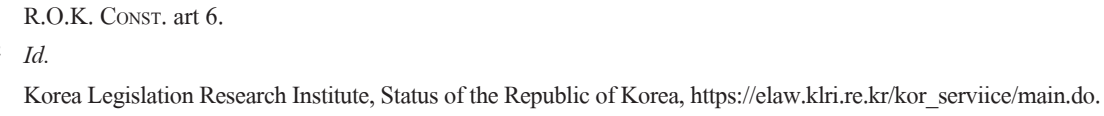


To protect the marine environment from the risks of various marine pollutants, South Korea enacted the Marine Environment Management Act (MEM Act) by incorporating all the technical annexes of the MARPOL 73/78. ${ }^{74}$ The MEM Act was first adopted in 1977 as the Marine Pollution Prevention Act, which was completely revised as the MEM Act on January 29, 2007 and again amended on October 31, 2017.

Before examining the detailed provisions for vessel-source pollution under the MEM Act, it is worth noting that Article 35 of the ROK Constitution provides a fundamental obligation for all citizens to endeavour to protect the environment, which is a vivid proof that the government of South Korea should make an effort to protect the environment in every possible way. As a result, such a constitutional basis serves as an institutional strategy for enacting environmental legislation or imposing penalties to infringements of environmental regulations.

\section{Marine Environment Management Act}

The MEM Act aims at offering the means necessary for the prevention, improvement, response, and recovery of marine pollution by managing sources that generate pollutants, such as vessels, marine facilities, and ocean spaces, as well as to regulate the discharge of marine pollutants, such as oil and noxious liquid substances. ${ }^{75}$ Furthermore, the Enforcement Decree of the MEM Act provides the means necessary for the enforcement delegated by the MEM Act. ${ }^{76}$ The technical regulations preventing vessel-source pollution, as well as any administrative rules, are included in the Rule on the Prevention of Marine Pollution from Ships, which deals with detailed provisions delegated by the MEM Act.

The Act applies to the management of the marine environment in the sea areas of South Korea, ships, marine facilities, etc. ${ }^{77}$ The Act is also applicable to ships flying the flag of South Korea and foreign ships sailing or berthed in the maritime zones of South Korea. ${ }^{78}$ Maritime zones laid down in the MEC Act cover territorial waters provided for in the Territorial Sea and Contiguous Zone Act, EEZs defined in Article 2 of the Act on the Exclusive Economic Zone and Continental Shelf (hereinafter Act of EEZ and Continental Shelf), and submarine mining areas designated pursuant to Article 3 of the Submarine Mineral Resources Development Act. ${ }^{79}$

74 ROK Marine Environment Management Act 2017 [해양환경관리법].

75 Id. art. 1.

76 ROK Enforcement Decree of the Prevention of Marine Pollution Act [선박에서의 오염방지에 관한 규칙], art 1.

77 Id. art. 3(1).

78 Id.

79 Id. 
More importantly, Article 2 (3) of the Act of EEZ and Continental Shelf emphasizes the agreement with the relevant states on the basis of international laws in delimitating the EEZ and continental shelf between South Korea and the states with opposite or adjacent coasts. ${ }^{80}$ Article 2(3) corresponds with the principle under Article 74 of the UNCLOS. South Korea cannot properly exercise the rights in EEZs in the area beyond the median line between them unless agreed separately between the relevant states and South Korea. ${ }^{81}$ The MEM Act may be thus difficult or even impossible to apply to the overlapping areas of EEZ between China and South Korea within the Yellow Sea unless agreed separately.

As to the detailed regulations over vessel-source pollution, the the ROK Ministry of Oceans and Fisheries imposes a marine environmental improvement charge on the ships that have discharged about 1,000 litres of oil into sea areas pursuant to Article 19 of the MEM Act. ${ }^{82}$ According to the discharge standards under the MEM Act, no one may discharge any pollutants from ships into the sea, except in exceptional circumstances and cases that meet the discharge requirements for garbage, HNS, and oil mixtures. Such discharge standards are followed by the MARPOL 73/78 and specifically mentioned in the Rule on the Prevention of Marine Pollution from Ships. ${ }^{83}$ Article 59 of the MEM Act enables the ROK Ministry of Oceans and Fisheries to exercise port state control against foreign ships in any harbour, port, or coastal area of South Korea that are not in compliance with the technical standards under an international agreement on marine pollution prevention such as MARPOL 73/78, anti-fouling systems, and ships' energy efficiency. ${ }^{84}$

Furthermore, a Port State Control Officer (PSCO) ${ }^{85}$ may order the master of foreign ships either to replace, remodel, change, repair, or improve the marine pollution prevention facilities or systems related to ship energy efficiency, or to take other necessary measures. ${ }^{86}$ Article 61 of the MEM Act requires the commissioner of the Korea Coast Guard to formulate and implement a national emergency pollution response plan to prevent and response to marine pollution. ${ }^{87}$ The provisions for

\footnotetext{
so ROK Act on the Exclusive Economic Zone and Continental Shelf [배타적 경제수역 및 대륙붕에 관한 법률], art. 2(3).

Id. art. 5(2)

32 ROK Marine Environment Management Act, art 19.

3 Id. art. 22.

84 Id. art. 59(1).

85 "A Port State Control Officer (PSCO) carries out port State control. The PSCO is a properly qualified person, authorized to carry out port State control inspections in accordance with the flag state administration, by the Maritime Authority of the port State and acts under its responsibility." See Paris MoU, https://www.parismou.org/about-us/psco.

86 Id. art. 59(2).

87 Id. art. 61.
} 
formulating and implementing a national emergency pollution response plan correspond with OPRC and OPRC/HNS 2000. Under Article 117 of the MEM Act, the Korea Coast Guard may stop, search, and seize a ship or prohibit a ship from entering into or departing from a port, or it can issue orders or take necessary measures if there are clear grounds to believe that a ship has violated the MEM Act within the maritime zones of South Korea. ${ }^{88}$ These rights are underpinned by the exercise of prescriptive and enforcement jurisdiction by a coastal state under Article 73, Article 211(3), and Article 220 of the UNCLOS.

\section{Ballast Water Management Act}

As the domestic law regarding the BWM, South Korea promulgated the Ballast Water Management Act (hereinafter BWM Act) on March 21, 2017. ${ }^{89}$ The BWM Act has incorporated all regulations for technical requirements, inspection, discharge standards, and certification and documents prescribed by the BWM. Similar to the MEM Act, the BWM Act may not apply to the overlapping sea areas of the EEZ within the Yellow Sea, which may lead to a legal vacuum in the exercise of coastal jurisdiction in accordance with the IMO conventions and domestic laws for preventing vessel-source pollution.

Article 4 of the BWM Act refers to the priority of international treaties or conventions against domestic laws..$^{90}$ Article 5 of the BWM Act stipulates: "Any ship entering into jurisdictional waters after taking up ballast water on board the ship at any waters must inform entry report with the Minister of Oceans and Fisheries." ${ }^{.91}$ The discharge of ships' ballast water or sediments is prohibited within the jurisdictional waters of South Korea, except for the cases that meet the discharge standards under Article 6 of the BWM Act. ${ }^{92}$ Article 7 of the BWM Act provides the legal basis to establish special zones for preventing the disturbance or destruction of the aquatic ecosystem by the infusion of harmful aquatic organisms. ${ }^{93}$ Based on Article 211(6) of the UNCLOS, all ships within special zones must refrain from the exchange, uptake and discharge of ballast water, and the ROK Ministry of Oceans and Fisheries may take appropriate measures over ships operating or anchored in the special zone. ${ }^{94}$

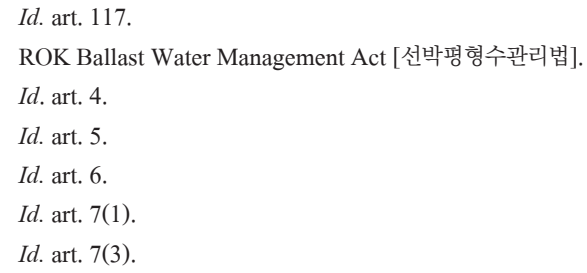


However, special zones have not yet been designated.

Whether South Korea is able to properly establish special zones in the overlapping areas of the EEZ between South Korea and China within the Yellow Sea through a unilateral declaration or action? Such a case would require the agreement or prior consultations for the designation of a special zone with opposite or adjacent coasts under international law. Article 28 of the BWM Act is concerned with port state control. Accordingly, a PSCO may inspect foreign ships within the maritime zones of South Korea to examine whether the ballast water management system of the ship conforms to the standards under the BWM Act. ${ }^{95}$ If the ship has violated the discharge standards or technical requirements, a PSCO may take further administrative measures. $^{96}$

\section{North Korea}

\section{General Principles}

The DPRK Constitution 2019 does not specifically contain provisions on the adoption and transposition of international treaties or conventions into domestic law. Instead, there are about 16 laws which lay down the provisions regarding the relationship between international and municipal law. ${ }^{97}$ The process for implementing international treaties or conventions is not systematically organised in North Korea, but it tends to accept international treaties or conventions as needed. ${ }^{98}$

Although North Korea signed the UNCLOS on December 10, 1982, it has not yet ratified the Convention. ${ }^{99}$ While North Korea did not officially declare the 12 $\mathrm{nm}$ limit of the territorial sea, its government has been asserting that the breadth of the territorial sea is $12 \mathrm{~nm}$ from the baselines since Resolution No. 25 of Cabinet of Ministers of March 5, 1955. ${ }^{100}$ It was reaffirmed in "Limit in the Seas No. 36" published by US Department of State Bureau of Oceans and International Environmental and Scientific Affairs and Maritime Agreement on Demarcation of the Soviet-Korean National Border. ${ }^{101}$ North Korea stated that the breadth of its territorial waters is up

95 Id. art. 28, Фศ 1-3.

$96 I d$. art. $28, \emptyset 4$.

97 Charn-kiu Kim \& KyU-Chang Lee, North Korean International Law [북한국제법연구] 84-5 [Table II-1] (2009).

98 Jang-Hee Lee, The Law of North Korea 50 Years: Trend and Perspective [북한법 50년, 그 동향과 전망] 276 (1999).

99 Division for Ocean Affairs and the Law of the Sea, United Nations Convention on the Law of the Sea: Declarations made upon signature, ratification, accession or succession or anytime thereafter (Feb. 13, 2020), https://www.un.org/ depts/los/convention_agreements/convention_declarations.htm.

100 Cabinet Ministers Resolution No. 25[내각결정 제25호] (adopted on Mar. 5, 1955). See also id. at 3.

101 R. Smith (ed.), Limits in the Seas No. 36: National Claims to Maritime Jurisdictions 87 (United States Department 
to $12 \mathrm{~nm}$ from baseline through INTERNATIONAL LAW DiCTIONARY published in $2002 .^{102}$ Although foreign vessels may enjoy the right of innocent passage in the territorial sea of North Korea, foreign warships must acquire prior permission or notification. ${ }^{103}$ It could be observed in the 1968 Pueblo incident. ${ }^{104}$ In relation to the EEZ regime, North Korea asserted $200 \mathrm{~nm}$ from [internal] baselines through the ordinance of North Korea's Central People's Committee on June 21, 1977. ${ }^{105}$ This ordinance might aim to establish the EEZ of North Korea for protecting, utilising, and exploiting its sea areas. The ordinance of North Korea's Central People's Committee provides:

foreign vessels, foreign aircraft, and foreigners must not conduct fishing, the installations of facilities, photographing, survey and research, exploration and exploitation, and other activities that become hampering economic activities in its EEZ without prior approval from North Korea, and North Korea prohibits all activities related to resulting in marine pollution, air pollution and creating hazards to human health, to harm living resources and marine life in its EEZ. ${ }^{106}$

The regime of North Korea's EEZ is similar to that of UNCLOS. On that basis, North Korea has promulgated the Regulation on the Economic Activities of Foreigners, Foreign Vessels, and Aircrafts in the Economic Zones of Democratic People's Republic of Korea on August 2, 1978 in order to effectively enforce its ordinance. ${ }^{107}$

of State Bureau of Oceans and International Environmental and Scientific Affairs, 2000), https://www.state.gov/ wp-content/uploads/2020/01/LIS-36.pdf. See also Agreement between the Union of Soviet Socialist Republics and the Democratic People's Republic of Korea on the Delimitation of the Economic Zone and the Continental Shelf [소비에트사회주의공화국연방과 조선민주주의인민공화국 사이의 경제수역 및 대륙붕 경계획정에 관한 조약](entered into force in May 1986).

102 See International Law Dictionary [국제법 사전] 180 (DPRK Academy of Social Sciences ed., 2002). See also Kim \& LEE, supra note 97, at 195.

103 P. Malanczuk, Akehurst's Modern Introduction to International Law 88 (7th ed. 2002). See also Kim \& LeE, id. at 198.

104 For details, see B. Young, A Reckless Act: The 1968 Pueblo Crisis and North Korea's Relations with the Third World (Wilson Center Report, Apr. 4, 2021), https://www.wilsoncenter.org/blog-post/reckless-act-1968-pueblo-crisis-andnorth-koreas-relations-third-world.

105 The Report on the Decree of June 21, 1977 on Establishing an Economic Sea Zone [조선민주주의인민공화국 경제수역을 설정함에 관하여]. For details, see DOALOS/OLA, Decree by the Central People's Committee establishing the Economic Zone of the People's Democratic Republic of Korea (adopted June 21, 1977), https://www.un.org/depts/ los/LEGISLATIONANDTREATIES/PDFFILES/PRK_1977_Decree.pdf; HeE Kwon Park, The Law of the SEA AND NortheAst Asia: A CHALlenge FOR COOPERATION 167 (2000); KYU-CHANG LeE, INTERNATIONAL LAW [북한의 국제법관] 528-9 (2008).

106 The Report on the Decree of June 22, 1977 on Establishing an Economic Sea Zone. For details see Chang-Hoon Shin \& Seok-Woo Lee, North Korea and the Law of the Sea, 8(1) Issues In Legal Scholarship (Frontier Issues in Ocean Law: Marine Resources, Maritime Boundaries, and the Law of the Sea) Article 5 (2008).

107 DPRK Regulation of August 12, 1978 on Economic Activities of Foreigners, Foreign Ships, and Foreign Aircraft in the Economic Waters [조선민주주의인민공화국 경제수역에서의 외국인과 외국배, 외국비행기들의 경제활동에 관한 
After North Korea joined the IMO on April 16, 1987, its officials have been participating in the diplomatic meetings of the IMO. Among the IMO conventions over vessel-source pollution, North Korea has ratified MARPOL 73/78, including its technical annexes, except for Annex VI. North Korea has also ratified the BUNKER convention. In this regard, Maritime Supervision Law (DPRK MSL) regulates that the matters related to maritime supervision that are not regulated under this law shall follow rules and regulations of international maritime conventions duly approved by DPRK. ${ }^{108}$ With regard to the compensation regime for pollution damage caused by oil pollution from ships, Article 40 of the Law concerning the Settlement of Maritime Accident (DPRK MAL) stipulates that North Korea imposes fines or compensation or detention on a foreign vessel that leads to maritime accidents in its maritime zone. ${ }^{109}$ In particular, Compensation for Damage Law clearly provides that the person who caused water pollution resulting from oil discharges shall compensate the damage. ${ }^{110}$ Supervisory institution will determine indemnifier and amount of compensation for pollution damage. ${ }^{111}$

Whether the IMO conventions concerning ships' safety and the prevention of marine pollution from ships are well implemented may be inferred from the 2019 Annual Report of Tokyo MoU on Port State Control. The 2019 Annual Report revealed that the detention percentage of ships used in international voyages flying the North Korean flag was recorded at 12 percent. ${ }^{112}$ It means that ships flying the North Korean flag had the highest detention rate among the Tokyo MoU member states. ${ }^{113}$ In this regard, North Korea's inability to implement the IMO instruments, as well as the country's lax rules and regulations, poses a threat to marine pollution and impedes maritime safety. Arguably, North Korea has neither established any procedure for implementing the IMO instruments in domestic laws, nor effectively contributed to enhancing maritime safety or protecting the marine environment by eliminating substandard ships. ${ }^{114}$

규정(1978년 8월 12일)]. See also J.W. Choi, Inter-Korean Fisheries Relations and the Law of the Sea Question [남북한 어업관계의 전개와 해양법문제], The Korean Institute OF NAVIGATION ANd PORT ReseARCH CONFERENCE Proc. [한국항해항만학회 학술대회논문집] 51 (June 2000).

108 DPRK Maritime Supervision Law 2020 [해사감독법], art.9.

109 DPRK Law concerning the Settlement of Maritime Accident 2016 [해난사고처리법], art. 40.

110 DPRK Compensation for Damage Law 2005 [손해보상법], art. 27.

111 Id.

112 Tokyo MoU, The Annual Report on Port State Control in the Asia-Pacific Region 2019 (2019), http://www.tokyo-mou. org/doc/ANN19-f.pdf.

113 Id.

114 M. John, Port State Control in the Asia-Pacific Region: Issues and Challenges, 1 Austl. J. Mar. \& OcEan Aff. 7387 (2009). 
Article 57 of the DPRK Constitution 2019 stipulates that "the State shall adopt measures to protect the environment, giving it preference over production, preserve and promote the natural environment and prevent environmental pollution so as to provide the people with a hygienic living environment and working conditions."115 Chung argued that, unlike South Korea and China, North Korea is seen as a mere tool to improve working conditions for the public - not as a fundamental obligation and responsibility of the government and individuals to protect the environment. ${ }^{116}$

\section{Environment Protection Law}

As a basic law regarding the environmental policy of North Korea, the Environment Protection Law (DPRK EPL) was enacted on April 9, 1986 based on Decision No. 5 of the Supreme People's Assembly. ${ }^{117}$ Then, it has been revised several times by ordinances (No. 488, No. 1676, No. 1083, No. 1482, No. 1825, No.3292, and No. 192) of the Presidium of the Supreme People's Assembly. ${ }^{118}$ The DPRK EPL consists of 58 articles with four chapters as follows: (1) General Principle for Protection Environment (Articles 1-9); (2) Preservation and Conservation of the Natural Environment (Articles 10-18); (3) Prevention of Environmental Contamination (Articles 19-41); and (4) Instruction and Control for Environmental Protection Work (Articles 42-58). ${ }^{119}$ Article 1 of the DPRK EPL provides: “... the EPL shall protect and promote people's health, and shall serve to make a hygienic living environment and working conditions for them..."

As to the prevention of vessel-source pollution, Article 27 of the DPRK EPL stipulates: "Ships sailing or anchored in the territorial waters and economic zones of our country shall keep the order related to pollution prevention, and ships sailing or anchored in ports, docks, floodgates, streams, lakes, or reservoirs must not throw away or drop things such as oil, wastewater, or garbage." ${ }^{, 121}$ Article 28 of the DPRK EPL outlines pollution prevention facilities of ships. Those agencies, associations, and

115 D.P.R.K. Const. 2019, art 37.

116 Chin Sok Chung, Marine Pollution: International Law and the Practice of the Yellow Sea States 214 (unpublished Ph.D. thesis, University of Bristol, 1999).

117 DPRK EnVIRONMENTAL ProteCtion LAw 2014 [조선민주주의인민공화국 환경보호법] (Daye Gang trans.), https://www. lawandnorthkorea.com/laws/environmental-protection-law-2014.

118 Hyung Chul Kim, A Study on Environmental Law System in North Korea [북한 환경법의 체계에 관한 연구; 환경보호법을 중심으로], 29(3) ENVTL. L. REv. [환경법연구] 189-225 (2007); Yoon Lee \& Eun Young Chah, Marine Pollution Prevention Law of North Korea [북한의「바다오염방지법」에 관한 법적, 경제적 고찰] 20(6) J. KoREAN Soc'Y MARINE ENVTL. \& SAFETY [한국해양환경,안전학회지] 712-20 (2014).

119 DPRK EnVIronmental Protection Law 2014, supra note 117.

120 Id. art. 1.

121 Id. art. 26. 
companies should be equipped with port reception facilities, and the discharge of pollutants from ships must be instantly handled through port reception facilities. ${ }^{122}$ Even though there are only four articles relevant to vessel-source pollution, the DPRK EPL provides basic discharge standards and technical requirements for the installation of marine pollution prevention equipment. These provisions may correspond with the discharge standards under MARPOL 73/78 to some extent.

Moreover, the DPRK EPL contains penalties and regulations against foreign vessels that have caused pollution damage in the maritime zones of North Korea. However, the DPRK EPL does not refer to any relations with international treaties or conventions and the priority of international law over national law. It does not provide delegation provisions that refer to specific technical requirements, and discharge standards, either. One question may arise whether a person who has suffered pollution damage from the accidental discharge of ships can file claims for compensation even if shipowners are entitled to limit their liability under their own national law. It seems that the compensation regime of North Korea does not correspond to international standard for pollution damage. However, the regulations of the DPRK EPL is close to the administrative sanctions imposed in North Korea via a penalty on the party who has committed an act threatening the environment. ${ }^{123}$ However, it is difficult to know whether North Korea has established measures for the remedy against the wrongful arrest of ships or unlawful actions.

\section{Ocean Protection Law}

As the concept of sub-decree for the DPRK EPL, the Supreme People's Assembly adopted the Ocean Pollution Prevention Law (DPRK OP Law) on October 22, 1997, which was amended on September 11, 2014 through Ordinance No. 142 of Presidium of the Supreme People's Assembly. The DPRK OP Law consists of a total of 60 articles. $^{124}$ The general principle for preventing marine pollution from ships is underpinned by the DPRK EPL.

Chapter 5 (Articles 41-54) of the DPRK OP Law deals with the regulations for the prevention of vessel-source marine pollution. Article 41 emphasizes the compliance with international conventions approved by DPRK. ${ }^{125}$ However, Chapter 5 does not contain detailed technical requirements and discharge standards under MARPOL

\footnotetext{
122 Id. art. 28.

123 Id. art. 55.

124 Lee \& Chah, supra note 118, at 715.

125 DPRK Ocean Pollution Prevention Law[바다오염방지법], art. 41.
} 
$73 / 78 .{ }^{126}$ Moreover, no cases have ever been reported on the application or any administrative enforcement over foreign vessels. ${ }^{127}$

\section{Conclusion}

This research has compared domestic laws of the Yellow Sea states over the prevention of vessel-source pollution through the perspective how the Yellow Sea states have implemented the IMO conventions through their domestic laws. Whether IMO conventions concerning vessel-source pollution are effectively implemented in national legislation is the point at issue of this research. It should be kept in mind that South Korea and China place an emphasis on protecting and conserving the environment as a constitutional obligation. In addition, South Korea and China have a significant constitutional bases to enact national laws protecting the marine environment.

Although the Yellow Sea states have domestic laws and regulations relating to the prevention of vessel-source pollution, there are no specific provisions for the coastal state to exercise their jurisdiction in the overlapping or disputed sea areas within the Yellow Sea. Unlike China and North Korea, Article 5(2) of the Act of EEZ and Continental Shelf of the Republic of Korea explicitly keeps South Korea from exercising its jurisdiction in the disputed sea areas unless agreed separately between the relevant states and South Korea. A comparative analysis of domestic laws of the Yellow Sea states shows that a legal vacuum exists in enforcing current domestic legislations of the Yellow Sea states over vessel-source pollution in an overlapping sea area within the Yellow Sea. Such legal vacuum should be made up by regulatory instrument to implement domestic laws under the IMO instruments. It will finally lead to the peaceful resolution of dispute from the vessel-sourced maritime pollution in an overlapping sea area within the Yellow Sea.

Received: August 1, 2021

Modified: September 30, 2021

Accepted: November 1, 2021

126 Sang-un Han, Integration of North and South Korea Marine Environmental Legislation and Its Challenges [북한 환경법제의 최근동향과 과제], 38(3) ENVTL. L. REV. [환경법연구] 1-19 (2016).

127 Id. 